\title{
The influence of statins on the free intracellular calcium concentration in human umbilical vein endothelial cells Stephan Heinke ${ }^{1}$, Gero Schwarz ${ }^{1}$, Hans R Figulla ${ }^{1}$ and Stefan H Heinemann*2
}

\author{
Address: ${ }^{1}$ Clinics for Internal Medicine I Med. Faculty of the Friedrich Schiller University Jena Erlanger Allee 101, D-07747 Jena, Germany and \\ ${ }^{2}$ Unit Molecular and Cellular Biophysics Med. Faculty of the Friedrich Schiller University Jena Drackendorfer St. 1, D-07747 Jena, Germany \\ Email: Stephan Heinke - svs.heinke@web.de; Gero Schwarz - gero.schwarz@gmx.de; Hans R Figulla - hr.figulla@med.uni-jena.de; \\ Stefan H Heinemann* - stefan.h.heinemann@uni-jena.de \\ * Corresponding author
}

Published: 04 May 2004

BMC Cardiovascular Disorders 2004, 4:4

This article is available from: http://www.biomedcentral.com/I47I-226I/4/4

(c) 2004 Heinke et al; licensee BioMed Central Ltd. This is an Open Access article: verbatim copying and redistribution of this article are permitted in all media for any purpose, provided this notice is preserved along with the article's original URL.

\begin{abstract}
Background: Statins are cholesterol-lowering drugs that are widely used to reduce the risk of cardiac infarction. Their beneficial clinical effects, however, are not restricted to their influence on cholesterol production. As several studies have shown that they have a potency of relaxing blood vessels.
\end{abstract}

Methods: We measured the effects of statins on the intracellular free calcium concentration $\left(\left[\mathrm{Ca}^{2+}\right]_{\mathrm{i}}\right)$ in human umbilical vein endothelial cells (HUVEC) after acute application and 24-hpreincubation of statins.

Results: Incubation of the cells for $24 \mathrm{~h}$ with cerivastatin or fluvastatin significantly increased the resting $\left[\mathrm{Ca}^{2+}\right]_{i}$. For cerivastatin this effect manifested at a concentration of I $\mu \mathrm{M}$. Increase of resting $\left[\mathrm{Ca}^{2+}\right]_{i}$ in the presence of cerivastatin also occurred when the nitric oxide synthase was inhibited. Transient $\mathrm{Ca}^{2+}$ release induced by histamine was not affected.

Conclusions: The increase of resting $\left[\mathrm{Ca}^{2+}\right]_{\mathrm{i}}$ after incubation with cerivastatin or fluvastatin may provide an explanation for the direct effects of statins on the endothelial-dependent vasodilatation and restoration of endothelial activity in vivo.

\section{Background}

Inhibitors of 3-hydroxy-3-methylglutaryl coenzyme A (HMG-CoA) reductase (statins) are drugs widely used in the treatment of hypercholesterolaemia. A large number of clinical trials (4S, CARE, WOSCOPS) has demonstrated that treatment of patients with statins reduces the number of cardiac or cerebral ischaemic events even in the absence of further reduction in serum cholesterol levels $[15,16]$.
In addition to their lipid-lowering activity, statins seem to possess relevant properties that target multiple mechanisms contributing to the progression of arteriosclerosis: leucocyte adhesion, macrophage stimulation, inflammatory responses, smooth muscle cell activation, and endothelial dysfunction. In patients with moderate hypercholesterolaemia, treatment with simvastatin improved both the acetylcholine-stimulated and basal nitric oxide 
mediated vasodilatation measured by use of strain-gauge plethysmography within one month [14]. Simvastatin produced relaxation of small resistance arteries of the rat through a mevalonate sensitive pathway [1]. Moreover, it was shown that simvastatin and atorvastatin reduced the concentration of endothelin 1 (ET-1) via a decreased expression of pre-pro ET-1 mRNA in bovine aortic endothelial cells. This effect persisted after the addition of oxidized low-density lipoprotein cholesterol [7]. Various statins inhibited superoxide anion $\left(\mathrm{O}_{2}^{-}\right)$formation and improved nitric oxide (NO) dependent vasodilatation through an influence on the $\mathrm{NO} / \mathrm{O}_{2}$ - balance in the vessel wall [18].

In endothelial cells, after treatment with simvastatin and lovastatin an up to 3.8 fold increase of eNOS expression was measured [9]. Other experiments have provided evidence for improved NOS mRNA stability after treatment with simvastatin [10]. Further it was shown that pravastatin and simvastatin increased the endothelium-dependent vasorelaxation in aortic rings and also the NO production by cultured bovine aortic endothelial cells [8].

Although these properties of statins may be relevant for their beneficial effects on cardiovascular diseases, they do not elucidate the signal pathway of statins on acute endothelium-dependent relaxation of blood vessels. eNOS is a calmodulin-binding enzyme and is abundantly expressed in endothelial cells. An increase of the cytosolic free calcium concentration subsequent to receptor stimulation through agonists like histamine or bradykinin is the main signal for stimulation of synthesis of $\mathrm{NO}$ in endothelial cells.

The aim of the present study was therefore to investigate the possible role of free intracellular calcium in the pathway of statin-induced endothelium dependent relaxation. For this purpose we examined the influence of two different statins (cerivastatin and fluvastatin) on agonistinduced transients and resting levels of $\left[\mathrm{Ca}^{2+}\right]_{\mathrm{i}}$ in cultured human endothelial cells.

\section{Methods}

Endothelial cells from human umbilical vein (HUVEC-p, Promocell, Heidelberg, Germany) were cultured in EGMMV Bulletkit medium (BioWhittaker, Verviers, Belgium) containing $0.1 \%$ human endothelial growth factor, $0.1 \%$ hydrocortison, $5 \%$ human serum, $0.4 \%$ bovine brain extract, $0.1 \%$ gentamycin. Cultures were maintained at $37^{\circ} \mathrm{C}$ in a fully humidified atmosphere with $5 \% \mathrm{CO}_{2}$ up to passage 6. SH-SY5Y human neuroblastoma cells (DSMZ Braunschweig, Germany) were cultured in DMEM medium containing $10 \%$ fetal calf serum (Gibco, Life Technologies, Eggenstein, Germany) in $10 \% \mathrm{CO}_{2}$. Cells were detached from the culture bottles by exposure to 0.5 $\mathrm{g} / \mathrm{l}$ trypsin in a $\mathrm{Ca}^{2+}$ and $\mathrm{Mg}^{2+}$-free solution for approximately $180 \mathrm{~s}$ and plated on gelatine-coated glass coverslips.

Changes of $\left[\mathrm{Ca}^{2+}\right]_{i}$ were measured fluorimetrically. The plated cells were loaded with Fura-2-AM (Molecular Probes, Eugene, USA) by incubating them for $40 \mathrm{~min}$ and $37^{\circ} \mathrm{C}$ at a dye concentration of $1 \mu \mathrm{M}$. After incubation, cells were washed 2 times with Krebs solution (see below) to remove extracellular Fura-2-AM. Fluorescence measurements were performed with a combination of a scanning monochromator and a CCD camera operated by TILLvisION software (Till Imago, T.I.L.L Photonics, Gräfelfing, Germany). The camera was mounted to an inverted microscope (Axiovert 100, Carl Zeiss, Jena, Germany) with a 40x objective (Neofluar, Carl Zeiss). Cells were exposed to alternating excitation light pules of 340 and $380 \mathrm{~nm}$ wavelength of each $200 \mathrm{~ms}$ at intervals of $2 \mathrm{~s}$. Emission images were collected during these pulses. Fluorescence values were corrected for background fluorescence before starting data collection from the emission images. Per experiment up to 8 cells were analyzed simultaneously by defining corresponding areas of interest in the images. The fluorescence intensity ratio $(F R)$, which is related to $\left[\mathrm{Ca}^{2+}\right]_{\mathrm{i}^{\prime}}$ was calculated for single cells over the whole experiment by forming the ratio of the fluorescence values at 340 and $380 \mathrm{~nm}$ excitation: $F R=\mathrm{F}_{340} / \mathrm{F}_{380}$ [6].

During the measurements, cells were continuously superfused with Krebs solution containing (in $\mathrm{mM}$ ): $\mathrm{NaCl} 140$, $\mathrm{KCl} 6, \mathrm{CaCl}_{2} 1.5, \mathrm{MgCl}_{2} 1.2$, HEPES 11.5, Glucose 10 and adjusted to $\mathrm{pH} 7.3$ with $1 \mathrm{M} \mathrm{NaOH}$; osmolarity was 295 mOsm. The application of all solutions was performed with an application tip located $3 \mathrm{~mm}$ away from the measured cells.

Cerivastatin (Bayer AG, Leverkusen, Germany) and fluvastatin (Novartis Pharma AG, Basel, Switzerland) were generously supplied by the respective companies. Cerivastatin and fluvastatin were dissolved in water [13]. $\mathrm{N}$-Omega-Nitro-L-Arginine (L-NAME) and histamine were purchased from Sigma-Aldrich Chemie (Taufkirchen, Germany).

To examine the long-term effects of statins on intracellular calcium homeostasis, cells were treated with the statins one day after seeding by adding appropriate volumes of stock solutions to the cell culture. Cells kept under the same conditions, but without statin treatment, served as control groups.

After $24 \mathrm{~h}$ statin incubation the cells were loaded with Fura-2-AM. FR was measured for $20 \mathrm{~s}$ under resting conditions, followed by an application of $10 \mu \mathrm{M}$ histamine for $60 \mathrm{~s}$ and washed out for about $120 \mathrm{~s}$. The mean value of 
$F R$ of each cell measured over $10 \mathrm{~s}$ was used for further analysis. To calculate the changes of $F R$ after $24 \mathrm{~h}$ incubation of statins, the FR-values of the incubated cells were normalized by dividing them through the average $F R$ value of all control cells of the respective experimental cycle resulting in $F R_{n}$.

In order to test the effect of acute application of statins, cells were incubated with Fura-2-AM as described above 1-2 days after seeding. Cells were superfused with control solution for $1 \mathrm{~min}$ in the experimental setup. Subsequently, histamine was applied up to three times at concentrations of 1-50 $\mu \mathrm{M}$ followed by a washout with control solution for 1-2 min. Statins were applied in concentrations of 50 and $100 \mu \mathrm{M}$ to resting cells as well as during stimulation with $10 \mu \mathrm{M}$ histamine.

All experiments were performed at room temperature between 20 and $23^{\circ} \mathrm{C}$. Means $\pm \operatorname{SEM}$ ( $n=$ number of cells) were calculated from pooled $F R_{n}$. Statistical significance was tested by means of the two-sided Student's t-test.

\section{Results}

The long-term effect of statins on the resting intracellular calcium concentration was measured by preincubation of HUVEC cells for $24 \mathrm{~h}$ with the respective statins. Since the resting $\left[\mathrm{Ca}^{2+}\right]_{i}$ levels varied from batch to batch, we expressed the statin effects as $F R_{n}$, i.e. always normalized the fluorescence ratio to the values obtained from nontreated control cells. For $10 \mu \mathrm{M}$ cerivastatin the $F R_{n}$ value was $1.104 \pm 0.0103(n=72, P<0.01)$. This means that statin incubation increased $F R$, which is a direct measure for an increase of the intracellular free calcium concentration, by $10.4 \% .5 \mu \mathrm{M}$ cerivastatin also increased $F R_{n}$ to $1.104 \pm$ $0.0237(n=17)$ and $1 \mu \mathrm{M}$ cerivastatin to $1.08 \pm 0.0113(n$ = 29). For $0.1 \mu \mathrm{M}$ cerivastatin $F R_{n}$ was $1.01 \pm 0.0122(n=$ $30)$ which was not significantly increased $(P=0.29)$. Incubation with $10 \mu \mathrm{M}$ fluvastatin increased $F R_{n}$ to $1.117 \pm$ $0.0263(n=25, P<0.01)$.

Thus, as summarized in Fig. 1, cerivastatin and fluvastatin significantly increased the fluorescence ratio under resting conditions.

The dependency of statin induced $\left[\mathrm{Ca}^{2+}\right]_{\mathrm{i}}$ increase on the driving force for $\mathrm{Ca}^{2+}$ was tested by application of extracellular solution containing $10 \mathrm{mM} \mathrm{CaCl}_{2}$. Application of the $10 \mathrm{mM} \mathrm{CaCl}_{2}$ solution up to $4 \mathrm{~min}$ did not change the resting calcium concentration of the cerivastatin treated cells $(10 \mu \mathrm{M}, 24 \mathrm{~h})$. Application of nominally $\mathrm{Ca}^{2+}$ free solution over up to $3 \mathrm{~min}$ did not change the resting $\left[\mathrm{Ca}^{2+}\right]_{i}$ either.

To investigate whether the increase of $\left[\mathrm{Ca}^{2+}\right]_{\mathrm{i}}$ after statin incubation is specific to endothelial cells, we repeated the protocol with SH-SY5Y human neuroblastoma cells. Incubation with $10 \mu \mathrm{M}$ cerivastatin did not lead to a significant change in $F R_{n}(0.972 \pm 0.0106, n=23, P=0.14)$.

Although endothelial cells do not express G kinase, Volk et al. have observed an NO-induced transient increase of $\left[\mathrm{Ca}^{2+}\right]_{i}[17]$. To check whether the increase of $\left[\mathrm{Ca}^{2+}\right]_{i}$ after incubation with statins was caused by an increase of NO due to a direct activation of eNOS by statins, we tested the effect of cerivastatin in the presence of L-NAME, an inhibitor of eNOS. L-NAME alone had no effect on $F R_{n}$. As shown in Fig. 1, $10 \mu \mathrm{M}$ Cerivastatin increased $F R_{n}$ also in the presence of $50 \mu \mathrm{M}$ L-NAME. Thus, we conclude that the observed effect of the statins on the resting calcium concentration is not a phenomenon common to all cells. In addition, it is not mediated by an direct $\left(\mathrm{Ca}^{2+}-\right.$ independent) effect of the statins on NO.

After $24 \mathrm{~h}$ incubation with one of the statins (or control group without statin) cells were stimulated with $10 \mu \mathrm{M}$ histamine. Almost all cells have shown a typical increase of $\left[\mathrm{Ca}^{2+}\right]_{i}$ (like those shown in Fig. 2). There was no obvious difference in the stimulated calcium transient pattern between the statin group and control group. Because of the large intercellular variability of the quantitative calcium response it was impossible to apply statistics for comparison between groups.

We further examined the effect of acute statin application to HUVEC cells on the resting $\left[\mathrm{Ca}^{2+}\right]_{\mathrm{i}}$ level as well as on histamine-induced $\mathrm{Ca}^{2+}$ release. Cerivastatin or fluvastatin at concentrations between 50 and $100 \mu \mathrm{M}$ were directly applied to the cells. In the absence of agonist, application of the statins for 1 to $5 \mathrm{~min}$ did not result in an effect on resting levels of $\left[\mathrm{Ca}^{2+}\right]_{\mathrm{i}}$. In Fig. $2 \mathrm{~A}$ such control applications are shown for fluvastatin.

The putative influence of statins on agonist-induced transients of $\left[\mathrm{Ca}^{2+}\right]_{\mathrm{i}}$ was tested with various protocols. As a control, a first $\mathrm{Ca}^{2+}$ transient was elicited with histamine only. The subsequent $\mathrm{Ca}^{2+}$ transient, again elicited with histamine, was then measured during simultaneous (Fig. 2B) or preceded statin application (Fig. 2C). In another series of experiments, statins were applied after the initial increase of $\left[\mathrm{Ca}^{2+}\right]_{\mathrm{i}}$ responding to the application of histamine, in order to test whether statins might primarily affect the return of $\left[\mathrm{Ca}^{2+}\right]_{\mathrm{i}}$ to basal levels. In none of these experiments histamine-induced $\mathrm{Ca}^{2+}$ signals in HUVEC cells were significantly altered by statins.

\section{Discussion}

There is ample of evidence for so-called pleiotropic effects of statins - beneficial and vasoprotective effects which are independent on the lipid-lowering properties of these substances. Various authors have shown that statins are 


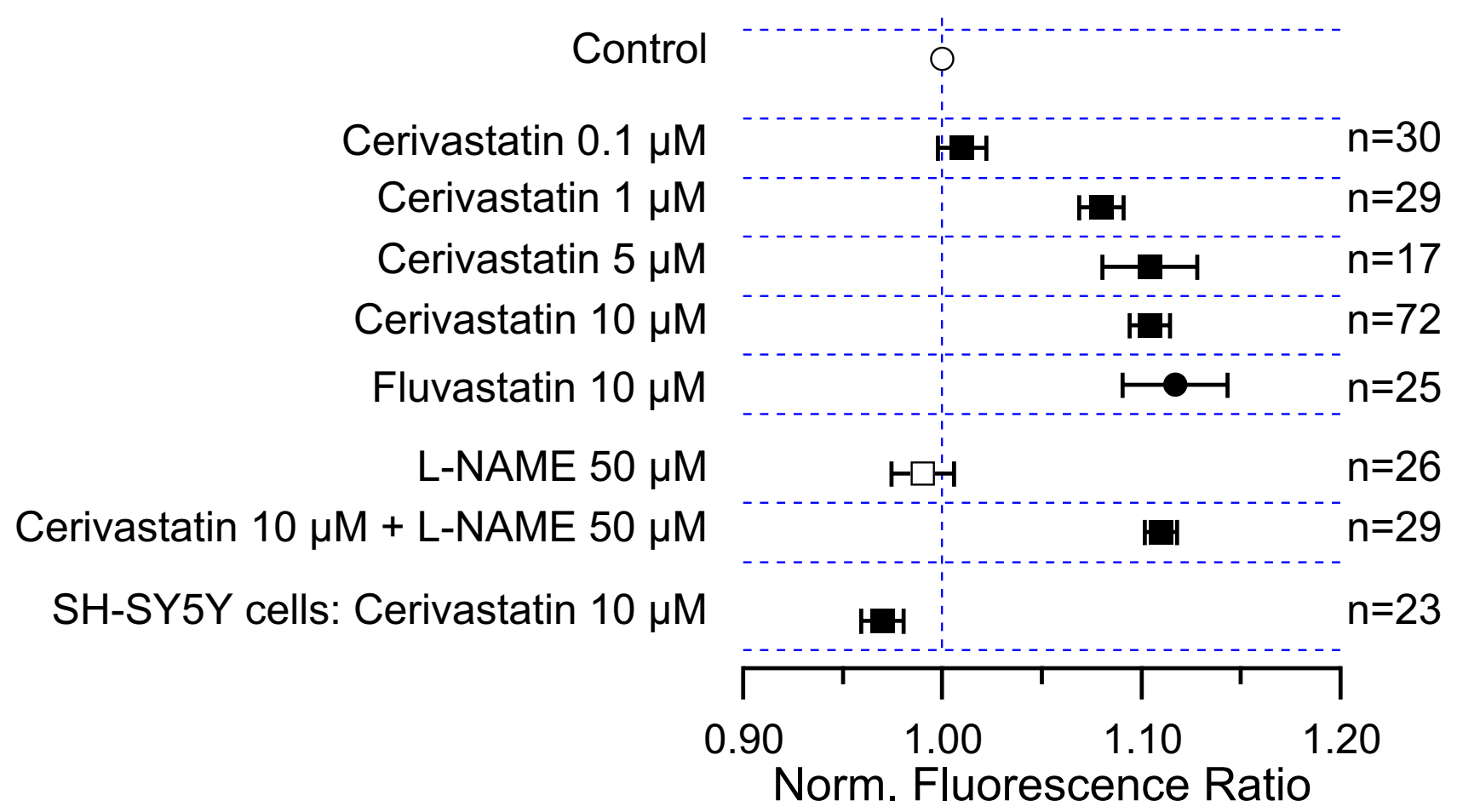

\section{Figure I}

Effect of 24-h statin incubation on the resting free calcium concentration. "Control" represents the mean fluorescence ratio $(F R)$ of control cells and was set to I. The other entries are FR values normalized to the mean FR of the respective control cells. The type of incubation, the SEM values as well as the number of analyzed cells $(n)$ are indicated. The last line shows experiments in which human SH-SY5Y neuroblastoma cells were incubated for $24 \mathrm{~h}$ with $10 \mu \mathrm{M}$ cerivastatin. All other experiments were performed with HUVEC cells.

capable of modulating the flow properties of blood vessels. In vivo studies have shown after a short period of statin administration to humans a significantly increased blood flow under resting conditions and after stimulation [14].

The underlying mechanism for this phenomenon is not completely understood. The results of Alvarez de Sotomayor et al. suggest that the improved vasodilatation is mainly mediated by an endothelium dependent relaxation which is induced by an increased production of nitric oxide [1]. An up-regulation of eNOS apparently plays an important role for this process $[3,10]$. However, not only an up-regulation of eNOS expression may be responsible for a statin-induced increase of blood flow. Also the direct activation of eNOS is likely to contribute to endothelium dependent relaxation [19].
Beside the activation of eNOS by mechanic stress, the calcium-calmodulin dependent activation of the enzyme in association with receptor-dependent and -independent agonists is the main pathway for the activation of eNOS; in contrast to iNOS, the activity of eNOS tightly correlates with $\left[\mathrm{Ca}^{2+}\right]_{\mathrm{i}}[4,5]$.

The concentration of free $\mathrm{Ca}^{2+}$ in the cytosol is extremly low, whereas the concentration in the extracelluar space and in the endoplasmatic reticulum is high. When a signaling molecule like Histamin binds to a G-protein-linked receptor, phospholipase C- $\beta$ becames activated. This enzyme generates two products: inositol triphosphate (IP3) and diacylglycerol. IP3 binds to IP3-gated $\mathrm{Ca}^{2+}$ release channels in the ER membrane. $\mathrm{Ca}^{2+}$ rushes into the cytosol, dramatically increasing the local $\mathrm{Ca}^{2+}$ concentration and triggering $\mathrm{Ca}^{2+}$-responsive proteins in the cells like eNOS: $\mathrm{Ca}^{2+}$ binds to Calmodulin, a specific $\mathrm{Ca}^{2+}$ 


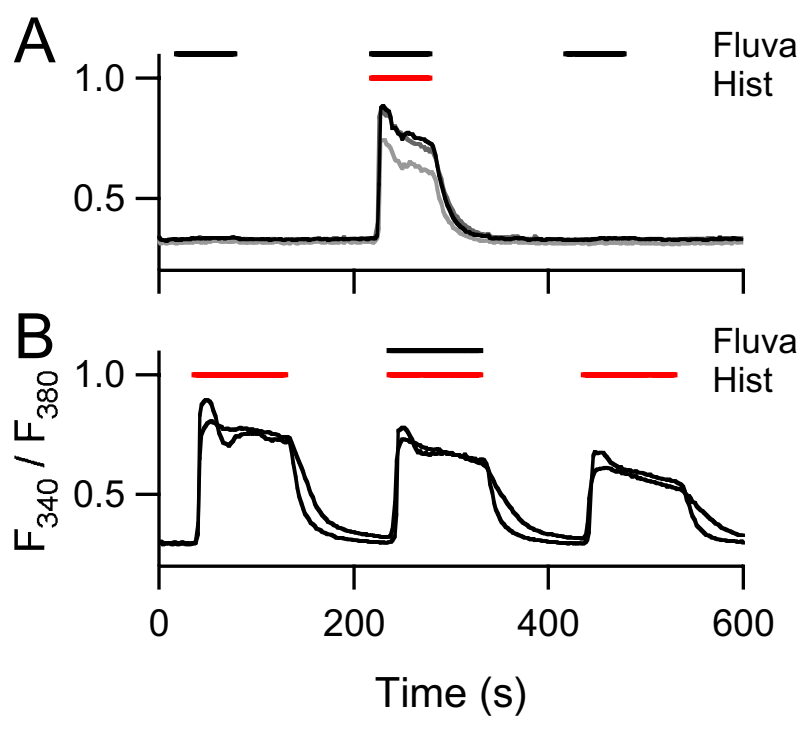

Figure 2

Histamine-induced transients in $\left[\mathrm{Ca}^{2+}\right]_{\mathrm{i}}$ (A) Fluorescence ratio of 3 cells. Application of $50 \mu \mathrm{M}$ fluvastatin without agonist followed by the application of histamine $(50 \mu \mathrm{M})$ and fluvastatin again. Compared with histamine, fluvastatin causes no changes of $\left[\mathrm{Ca}^{2+}\right]_{i}$. The very small waves of the baseline after the application of fluvastatin were not distinguishable from the normal baseline fluctuations which can always be observed when small changes of fluid flow or level in the experimental chamber are encountered (also see end of this record). (B) Records of the fluorescence ratios of 2 cells. Application of $50 \mu \mathrm{M}$ histamine 3 times, during the second stimulation co-application of $50 \mu \mathrm{M}$ fluvastatin. No specific effect caused by the application of fluvastatin was observed. The $\mathrm{Ca}^{2+}$ transients elicited by repeated histamine stimulations slightly decrease in amplitude. This is a normal phenomenon in endothelial cells and is not related to statin application.

binding protein. It undergoes a conformational change when it binds $\mathrm{Ca}^{2+}$, but it has no encyme activity itself. It acts by binding to other proteins and therby altering their activity. In this way it activates eNOS. It is well documented that $\mathrm{IP}_{3}$-mediated $\mathrm{Ca}^{2+}$ release is also controlled by cytoplasmatic $\mathrm{Ca}^{2+}$ concentration [11]. Small increases in calcium concentration around 100-300 nm enhance the activity of the IP3 receptor dramatically.

With the presented experimental results we have shown a small but significant increase in resting levels of $\left[\mathrm{Ca}^{2+}\right]_{i}$ induced by treatment with cerivastatin and fluvastatin. This small increase of $\left[\mathrm{Ca}^{2+}\right]_{i}$ possibly represents a major contribution to the enhancement of endothelium derived relaxation of blood vessels in vivo and in vitro, since allos- teric regulation of eNOS by calcium-calmodulin and the modulation of IP3 receptor activity by intracellular calcium can multiply this effect.

It is difficult to compare an endothelium cell under resting conditions with an endothelium cell in an intact blood vessel under normal flow conditions. However, our results are in accordance with the investigation of O'Driscoll et al. that indicates that L-NAME-mediated vasoconstriction is enhanced after treatment with statins, indicative of an augmented basal effect of NO [14].

After $24 \mathrm{~h}$ incubation with statins we could not observe obvious changes of histamine-induced $\mathrm{Ca}^{2+}$ transients. Because of a broad intercellular variety of histamineinduced $\mathrm{Ca}^{2+}$ transients, a quantitative comparison between groups was not feasible. Furthermore, direct comparison of the $\mathrm{Ca}^{2+}$ response to histamine for one cell before and after incubation with statins was technically not possible.

We did not find any acute effect of statin treatment on $\left[\mathrm{Ca}^{2+}\right]_{\mathrm{i}}$. This result is in accordance with the described in vivo results. Because of the broad intercellular variety in agonist-induced $\mathrm{Ca}^{2+}$ signals in HUVEC cells and the long lasting statin incubation it will not be feasible to perform experiments on single cells to explore the role of the intracellular calcium stores and calcium pumps for the observed effects.

One possible pathway leading to the increase in $[\mathrm{Ca} 2+] \mathrm{i}$ after incubation with statins could be via an increase of NO by means of direct eNOS activation by statins [17]. To exclude this hypothesis we compared cells incubated with $10 \mu \mathrm{M}$ cerivastatin alone and cells incubated with $10 \mu \mathrm{M}$ cerivastatin and $50 \mu \mathrm{M}$ L-NAME as an inhibitor for the eNOS. In contrast to other L-Arginine inhibitors like LNMMA, L-NAME has a different selectivity to the three NOS isoforms. The selectivity iNOS / eNOS is reported with 0,05 and the pIC50 with 5,82 for human isoencymes [2]. So, L-NAME is not highly active for eNOS inhibition, but for the applied concentration of $50 \mu \mathrm{M}$ in HUVEC we expected a satisfied and selective inhibition of eNOS.

Because there was no significant difference of the changes of the on $\left[\mathrm{Ca}^{2+}\right]_{i}$ caused by cerivastation with or without L-NAME, we conclude that the observed effects of statins on $\left[\mathrm{Ca}^{2+}\right]_{i}$ are not indirectly mediated by NO.

\section{Conclusions}

Incubation of the cells for $24 \mathrm{~h}$ with cerivastatin or fluvastatin significantly increased the resting $\left[\mathrm{Ca}^{2+}\right]_{\mathrm{i}}$. Increase of resting $\left[\mathrm{Ca}^{2+}\right]_{\mathrm{i}}$ in the presence of cerivastatin also occurred when the nitric oxide synthase was inhibited. Transient $\mathrm{Ca}^{2+}$ release induced by histamine was not affected. 
Recently published results of Mizuno et al. have shown that there is a clearly quantitative relationship between the concentration of $\left[\mathrm{Ca}^{2+}\right]_{i}$ and NO production [12]. The relationship between the integrated $\left[\mathrm{Ca}^{2+}\right]_{\mathrm{i}}$ and NO production was described by a straight line. This encourages us in the assumption that the observed changes of $\left[\mathrm{Ca}^{2+}\right]_{i}$ through statins could be one possible mechanism for the improvement of endothelial function after treatment with these substances in vessels challenged by arteriosclerosis.

\section{Competing interests}

None declared.

\section{Abbreviations}

eNOS, endothelial nitric oxide synthase; HUVEC, human umbilical vein endothelial cell; L-NAME, N-Omega-NitroL-Arginine; $\left[\mathrm{Ca}^{2+}\right]_{i^{\prime}}$ intracellular free calcium concentration; HMG-CoA, 3-hydroxy-3-methylglutaryl coenzyme A

\section{Authors' contributions}

SH participated in the design of the study, carried out the cell experiments, performed the statistical analysisand drafted the manuscript.

GS participated in the cell experiments and drafted the manuscript.

HRF participated in the design and coordination of the study.

SHH participated in the design and coordination of the study.

All authors read and approved the final manuscript.

\section{Acknowledgements}

We thank Angela Roßner for the excellent cell culture and Novartis AG and Bayer AG for supporting this study.

\section{References}

I. Alvarez de Sotomayor M, Herrera MD, Marhuenda E, Andriantsitohaina R: Characterization of endothelial factors involved in the vasodilatory effect of simvastatin in aorta and small mesenteric artery of the rat. Br J Pharmacol 2000, I 3 I : I | 79- I I 87.

2. Boer R, Ulrich WR, Klein T, Mirau B, Haas S, Baur I: The inhibitory potency and selectivity of arginine substrate site nitric-oxide synthase inhibitors is solely determined by their affinity toward the different isoenzymes. Mol Pharmacol 2000, 58(5): 1026-34.

3. Endres $M$, Laufs U, Huang $Z$, Nakamura $T$, Huang $P$, Moskowitz MA, Liao JK: Stroke protection by 3-hydroxy-3-methylglutaryl (HMG)-CoA reductase inhibitors mediated by endothelial nitric oxide synthase. Proc Natl Acad Sci USA 1998, 95:8880-8885.

4. Fleming I, Busse R: Signal transduction of eNOS activation. Cardiovasc Res 1999, 43:532-54I.

5. Govers R, Rabelink TJ: Cellular regulation of endothelial nitric oxide synthase. Am J Physiol Renal Physiol 200I, 280:FI 93-206.

6. Grynkiewicz G, Poenie M, Tsien RY: A new generation of $\mathbf{C a}^{2+}$ indicators with greatly improved fluorescence properties. J Biol Chem 1985, 260:3440-3450.

7. Hernandez-Perera O, Perez-Sala D, Navarro-Antolin J, Sanchez-Pascuala R, Hernandez G, Diaz C, Lamas S: Effects of the 3-hydroxy-
3-methylglutaryl-CoA reductase inhibitors, atorvastatin and simvastatin, on the expression of endothelin- $I$ and endothelial nitric oxide synthase in vascular endothelial cells. J Clin Invest 1998, 101:27||-27|9.

8. Kaesemeyer WH, Caldwell RB, Huang J, Caldwell RW: Pravastatin sodium activates endothelial nitric oxide synthase independent of its cholesterol-lowering actions. Am Coll Cardiol 1999, 33:234-24I.

9. Laufs U, la Fata $\mathrm{V}$, Plutzky J, Liao JK: Upregulation of endothelia nitric oxide synthase by HMG CoA reductase inhibitors. Circulation 1998, 97: I 129-1 I35.

10. Laufs U, Liao JK: Post-transcriptional regulation of endothelia nitric oxide synthase mRNA stability by Rho GTPase. J Biol Chem 1998, 273:24266-2427I.

I I. Mak DO, McBride S, Foskett JK: Inositol I,4,5-trisphosphate activation of inositol trisphosphate receptor $\mathrm{Ca2}+$ channel by ligand tuning of $\mathrm{Ca2+}$ inhibition. Proc Natl Acad Sci U S A 1999 , 95(26): $1582 \mid-5$

12. Mizuno O, Kobayashi S, Hirano K, Nishimura J, Kubo C, Kanaide H: Stimulus-specific alteration of the relationship between cytosolic $\mathrm{Ca}^{2+}$ transients and nitric oxide production in endothelial cells ex vivo. Br J Pharmacol 2000, I30: I I40-I I 46.

13. Muck W: Clinical pharmacokinetics of Cerivastatin. Clin Pharmacokinet 2000, 39:99-116.

14. O'Driscoll G, Green D, Taylor RR: Simvastatin, an HMG-coenzyme $A$ reductase inhibitor, improves endothelial function within I month. Circulation 1997, 95: II26-II3I.

15. Sacks FM, Pfeffer MA, Moye LA: The effect of Pravastatin on coronary events after myocardial infarction in patient with average cholesterol levels. N Engl J Med 1996, 335:100I-1009.

16. Shepherd J, Cobbe SM, Ford I: Prevention of coronary heart disease with pravastatin in men with hypercholesterolemia. West Of Scotland Coronary Study Group. N Engl J Med 1995, 333: $1301-1307$

17. Volk T, Mading K, Hensel M, Kox WJ: Nitric oxide induces transient $\mathrm{Ca}^{2+}$ changes in endothelial cells independent of cGMP. J Cell Physiol 1997, 172:296-305.

18. Wagner AH, Kohler T, Ruckschloss U, Just I, Hecker M: Improvement of nitric oxide-dependent vasodilatation by HMG-CoA reductase inhibitors through attenuation of endothelial superoxide anion formation. Arterioscler Thromb Vasc Biol 2000, 20:6I-69.

19. Yamada M, Huang Z, Dalkara T, Endres M, Laufs U, Waeber C, Huang PL, Liao JK, Moskowitz MA: Endothelial nitric oxide synthasedependent cerebral blood flow augmentation by L-arginine after chronic statin treatment. J Cereb Blood Flow Metab 2000, 20:709-717.

\section{Pre-publication history}

The pre-publication history for this paper can be accessed here:

http://www.biomedcentral.com/1471-2261/4/4/prepub

Publish with Bio Med Central and every scientist can read your work free of charge

"BioMed Central will be the most significant development for disseminating the results of biomedical research in our lifetime. "

Sir Paul Nurse, Cancer Research UK

Your research papers will be:

- available free of charge to the entire biomedical community

- peer reviewed and published immediately upon acceptance

- cited in PubMed and archived on PubMed Central

- yours - you keep the copyright 